\title{
Filming Change: Civil Rights through the Lens of Guess Who's Coming to Dinner? and To
}

\section{Kill a Mockingbird}

Keywords: civil rights, racism, sexism, Guess Who's Coming to Dinner?, To Kill a Mockingbird, sixties, social change

Abstract: The 1960s were a turbulent decade in the United States. Significant social changes, especially in the realm of antiracism and antisexism, were afoot. Concurrently, in an echo to such dramatic social change, popular culture was also evolving. This article examines two relevant films to evaluate their ability to perform a moral critique of gender and racial politics in the 1960s. Alongside an analysis of social and political trends and Supreme Court cases, I compare two critically acclaimed industry films, To Kill a Mockingbird (1962) and Guess Who's Coming to Dinner (1967), to better understand cultural and political reforms in the 20th century.

The 1960s were a turbulent decade in America. Significant social changes were unfolding, including the Civil Rights Act (1964); Voting Rights Acts (1965); the assassinations of President John F. Kennedy (1963), Malcolm X (1965), Rev. Dr. Martin Luther King, Jr. (1968), and Robert Kennedy (1968); student protests against the Vietnam War (which began in 1964); the establishment of Black nationalist parties, especially the Black Panther Party (1966); and the rise of second-wave feminism, with demands for equality on issues related to sexuality, family, the workplace, and reproductive rights manifested, in part, by the Presidential Commission on the Status of Women (1961), the Equal Pay Act (1963), Title VII (1964), and the founding of the National Organization for Women (NOW) in 1966. In the summers of 1964-8,

\footnotetext{
${ }^{*}$ Mary K. Ryan is an Assistant Professor of Political Science and Public Policy at Washington \& Jefferson College. She received her Ph.D. in Social, Political, Ethical, and Cultural Thought from Virginia Tech and has published numerous articles and book chapters on poverty, race, democratic theory, social justice, and popular culture (especially film and theater).
} 
there were hundreds of riots across hundreds of American cities. In short, as Kevern Verney describes, 1960s "America was a country at unease with itself" (68).

Concurrently, in an echo to such dramatic social change, popular culture was also evolving. Taking this into account, this article examines two relevant films to evaluate their ability to perform a moral critique of gender and racial politics in the 1960s. Specifically, I compare two critically acclaimed industry films, To Kill a Mockingbird (1962) directed by Robert Mulligan, and Guess Who's Coming to Dinner (1967) directed by Stanley Kramer (hereinafter referred to as Dinner and Mockingbird, respectively). ${ }^{1}$ While much has been written about these two films independently, they are scarcely considered as a pair. I aim to correct this oversight, given how influential both films were in shaping a generation, as well as offering lessons to a new generation, filled with a renewed urgency and activism.

These films are selected because they serve as excellent depictions of "social problem films," the which this article assumes to be the most useful when performing moral critique. "Social problem films" are especially useful for understanding how social change is reflected in popular culture. So-called "message films," they put serious issues under the microscope in the historical moment of the time. Typically narrative in structure, social problem films both integrate and interrogate a larger social conflict by way of individual conflict between the film's characters (Cagle 2005). Often, these films deal with concepts like racial conflict, slavery, or inhumanity. While this type of film dates back to the 1920s, it flourished in the 1950s and 1960s against an evolving sociopolitical backdrop in U.S. history. Both films discussed in this article tackle racism, but they also address sexism, gender roles, and generational differences in the acceptance of social norms. A better understanding of "social problem films" like these two 
affords the nation a chance to better understand and effectively monitor political and cultural progress in society.

Dinner is a 1967 Columbia Pictures film which was nominated for ten Academy Awards and won Best Actress (Katharine Hepburn) and Original Screenplay. The film was a major box office success across the nation, earning nearly 14 times its budget. Directed by Stanley Kramer, Dinner is set as a contemporary film in 1967 which follows one family's reactions to and anxiety with experiencing interracial marriage. After a vacation in Hawaii, Joanna "Joey" Drayton (played by Hepburn's real-life niece Katharine Houghton) makes a surprise trip home to announce her engagement. She returns, along with her new successful Black fiancé Dr. John Prentice (played by Sidney Poitier), to share the news and get the blessing of her White, liberal, upper class parents in California. The film shows Joey's parents' (played by Hepburn and Spencer Tracy), referred to as Christina and Matt, as well as Dr. Prentice's parents (played by Beah Richards and Roy Glenn), whose first names are unknown and are only referred to as Mr. and Mrs. Prentice, grappling with their children's Black-White romance, especially under the pressure of having to reach a decision to give their blessing within the same day. Dinner is widely recognized as first major motion picture to feature an on-screen kiss between a White woman and a Black man (Perrin).

Dinner was a controversial film. The behind-the-scenes interviews accompanying the DVD reveal that both the film's director and the actress who played the role of the White daughter, Joey Drayton, received death threats from White supremacists. While it is considered provocative and groundbreaking by many, it is also criticized by some for relying on stereotypical reactions and depicting the Black fiancé as so flawless he is essentially unobjectionable (Verney 69). African American playwright Clifford Mason considered the 
character to be a "showcase nigger wearing a clean suit" with a "complete purity of motivation" that created the appearance of Poitier's character as "a mistreated puppy with all the sympathy on his side" (qtd. in Verney 69).

Mockingbird is a 1962 Universal Studies film which was nominated for eight Academy Awards and won Best Actor (Gregory Peck), Best Adapted Screenplay, and Best Art Direction. The character Atticus Finch has been named the greatest movie hero of the $20^{\text {th }}$ century by the American Film Institute. The film was a major box office success, earning ten times its budget. Mockingbird is set in an Alabama town during the Great Depression. The widowed, White lawyer Finch (played by Peck) is appointed to defend Tom Robinson (played by Brock Peters), a poor Black man accused of raping a poor young White woman named Mayella Ewell (played by Collin Wilcox). This film takes place over three years and is often attributed as a coming-of-age story for Finch's children, Scout and Jem. Although this film is often discussed from the perspective of Scout, I am primarily interested in the interracial relationship and abuse which is on trial, and, accordingly, in the characters Robinson, Finch, and Ewell.

\section{The Film Industry}

The film industry of the 1960s attempted to mirror social and political trends, striving to bear witness to the changes taking place in society by representing a myriad of fresh voices and perspectives that had not been heard in earlier decades. By the late $60 \mathrm{~s}$, "the leading cinema attractions for US audiences...involved more sobering portrayals of social and racial problems" (Verney 68). To Kill a Mockingbird's film star Gregory Peck coincidentally served as President of the Academy of Motion Picture Arts and Sciences in 1967, the year when Guess Who's 
Coming to Dinner? was nominated. He reflected "Dr. King's influence on the society in which we live is that of the five films nominated best picture of the year, two dealt with the understanding between the races" (Perrin 850).

Although increasing numbers of films in the 1960s were focused on race and social issues, the trend should not be overstated. In 1967, of the 3,508 roles available in film and television, only 159-a paltry .045 percent—went to African American actors (Wheeler 132). Poitier is widely regarded as "the first black superstar in Hollywood" and it is evident he was in a category by himself at the time (Verney 55). Class and gender hierarchy preserve the social category of race in films (Perrin 846). The film industry struggled with the complexities embedded in the process of accomplishing racial diversity; it found that "reading 'race' in our culture-high or low, popular or elite-is a large and difficult enterprise" (Appiah 77). This difficulty is illuminated in comparison to interracial relationships.

\section{Interracial Relationships}

Renee Romano's landmark book Race Mixing provides an extensive historical framework to understand Black-White marriage in America. The earliest national Gallop poll on this topic was conducted in 1958. As Romano reports, a staggering 96 percent of Whites disapproved of marriages between Blacks and Whites in the first poll. Blacks were not polled on the subject until 1972. The U.S. Census Bureau first began tracking the number of interracial couples in 1960; at that time, there were 51,000 Black-White married couples (Romano 3).

Anne Gray Perrin observes that "laws criminalizing sexual interracial relationships go as far back as the seventeenth century," with Maryland passing the first miscegenation statute that 
outlawed marriage between White women and Black men in 1661 (847). Romano notes that in 1940 marriages between Blacks and Whites were illegal in thirty-one of the forty-eight states, but only six states barred interracial fornication (5). As late as 1967, sixteen states still made it illegal for Blacks and Whites to marry (Romano 2). The taboo against intimate interracial relationships was crucial to maintaining a hierarchy that privileged Whites over Blacks in America's racial order and can be traced back to the establishment of the country's early slave system (Romano 4).

Romano also discusses how the 1954 Supreme Court decision in Brown v. Board of Education mobilized an intense societal debate between those who sought to preserve "racial purity" as a public policy objective and those who thought interracial relations were a private, not public, matter (143). Numerous Supreme Court cases in the 1960s served to move the needle on important social policies. Most famously, in 1967 the Supreme Court declared all antimiscegenation laws, laws prohibiting interracial marriage, unconstitutional in Loving $v$. Virginia (Romano 185). Before this landmark decision, there were several other important cases which created a precedent for change. With 1964's McLaughlin v. Florida case, the Supreme Court overturned the 1881 Pace v. Alabama precedent and made it illegal to ban cohabitation among unmarried interracial couples (Romano 188). In the case of Davis v. Gately, the Supreme Court also ruled in the 1967 that it was unconstitutional to refuse the issuance of a marriage license due to objection on racial grounds (Romano 187).

\section{Patriarchy \& Patrimony}

Both Mockingbird and Dinner are films centered on family, especially the father figures. In this section, I will discuss the films' relationship to patriarchy and patrimony. This article 
understands patriarchy in America to function as a social system in which the father or male head of the family holds the power and women are largely excluded from it. Patrimony is understood to refer to inheritance, legacy, or heritage from a father. Inspired by the sociological connections made by Mounira Charrad in her article "Central and Local Patrimonialism: State-Building in Kin-Based Societies," I am connecting patrimony with patriarchy as part of investigation into the ways they determine or validate political power in the formation of the state or government. Given the overarching interest this article has in fostering societal change, the role and power men have, especially historically, is a vitally integral factor to analyze in a democratic society.

A cultural transition in family values was emerging in the 1960s and the film industry was taking note. In Dinner, Perrin discusses how both fathers use Joey to realize their own principles (851). Renee Romano, like Harris, considers Tracy's character to be the archetypal American father figure (202). Tracy's character leads the film's extended discussion of intermarriage in Dinner; it is also arguably one of the most sustained discussions in film history on intermarriage. In the film, Romano observes how the character Matt Drayton is an outlet for "the angst White liberals, especially men, felt about their ability to overcome internalized racial feelings and to truly accept blacks as their equals" (201). Dinner presents the issue of interracial marriage as both a result of the White liberal teachings and as a challenge to liberal beliefs (Romano 201). In this way, the film becomes popular with White audiences because many wondered how racial and social changes might impact their own families (Romano 203). Moreover, the process in which the film tackles the question of intermarriage reinforces White patriarchy, making it risky for White audiences yet bounded safely in tradition. As Romano states, "by giving Matt Drayton the power to prevent the marriage, the film gave the white patriarch ultimate control of the situation" (204). But this control was not universally accepted. 
In the late 1960s, the role of the father-figure was under fire in America. As Mark Harris observes, "Half of the Best Picture nominees seemed to be sneering at the other half: The fatherknows-best values of Guess Who's Coming to Dinner? were wittily trashed by The Graduate" (2).

Patrimonialism was not threatened in the sixties only by Black-White marriage. A second social change was afoot in the form of feminism and individual liberties. The premise of Dinner assumes that the White father has the ultimate say in whom his daughter marries. Romano observes that 'when segregationists ask 'Would you want your daughter to marry one?' they assumed that a daughter would ask her father's permission. By the late 1960s, it could not be safely assumed that a daughter (or son) would ask permission to intermarry, or that young people would have the same qualms about intermarrying as their parents did" (212). Linda Williams argues that racial categories in film serve to signify legitimate signs of the family; in fact, race may be more powerful than paternity. Williams contends that "ascriptions of race actually replace paternity as the ultimate mark of belonging to a family" (59). This makes the setting of the home in a film so fraught with drama.

\section{Stereotypical Representations of Black Men}

Both Mockingbird and Dinner feature Black men, Robinson and Prentice, as central plot fixtures in the films. Mockingbird portrays Robinson as desperate, uneducated, and impoverished. In Dinner, Glen Anthony Harris objects to Prentice's “superman” status because he finds it does not reflect the actual educational attainment of Black men due to educational 
boundaries at the time (Harris and Toplin 700-713). Two of the dominant theories about Black men in film are addressed in this section.

The first portrayal concerns the notion of the Black man as saint. These characters are depicted as uncommonly noble, decent, good-hearted, friendly to Whites, and seemingly working-class but better educated than most working-class Americans. Contemporary films which feature Black male characters like this include Driving Miss Daisy (1989), Ghost (1990), and Grand Canyon (1991), but the practice began in Dinner with the role of Prentice (Appiah 80-85). Prentice's "superior Black man" performs the sanctimonious act of both turning the "possibility of marriage to Hepburn and Tracy's daughter into a genuine ethical dilemma" and then winning their daughter's hand in marriage (Appiah 82). Thomas Cripps also observes that Poitier's portrayal of the "saintly United Nations' physician is made to seem, as a result of his outsized virtues, eligible to marry a rich white woman," making him "the beau ideal of the era" (157). There are two dominant explanations for why the Saint portrayal exists in films. One draws on the Christian notion that, since suffering is ennobling, the Black person who represents undeserved suffering in American imagination can be construed to represent moral nobility, and the other suggests that the Saint exists to assuage the guilt of White audiences who are afraid that Black people are angry at them for centuries of oppression, wanting to be forgiven, and, thus, create a Black man who is admirable, loveable, and loves White people back (Appiah 83).

The second depiction of Black men in film completely reverses the saint depiction by painting African Americans as criminals. Dennis Rome refers to this as the "black demon" stereotype whereby "to successfully subjugate and exploit a group, negative stereotypes become tools of ideological formation that operate, in part, to suggest that the subordinate group is deserving of such treatment or status" (46). The slander and persecution of Tom Robinson by 
poor, bigoted White men in Mockingbird-which is set during the Great Depression instead of the time of its filming in 1962, allowing audiences space to reflect back and correct prior social illsdemonstrates a strategy "used to perpetuate dominate society's continued fear and subjugation of African Americans" (46). Mark Holcomb classifies Tom Robinson in Mockingbird as "an implicit hypersexualized threat" (39). The "myth of the Black rapist" was first identified by Frederick Douglass and it was used to legitimize lynching. In 1910, Ida B. Wells-Barnett echoed these sentiments, observing that White people's calls for chivalry and depictions of Black men ravaging White women were hollow. She describes a hysteria to keep the Black and White races separate at all costs in order to prevent "race pollution" which, in turn, legitimized lynching (Wells 42-53). While Mockingbird portrays Robinson on trial being held legally culpable for a crime which he did not commit (and plausibly could not commit due to a permanent disabling injury of his arm wrangled in a cotton gin), Rome importantly notes that Jim Crow laws infiltrated all aspects of Black people's lives. The social and political pervasiveness of the persecution was, in his reading, most sensationalized by attacks and lynchings concerning the "ultimate symbol of Black autonomy, sexual access by Black men to White women. Beyond this could lie only the nightmare of interbreeding and the blurring of caste lines" (Rome 48). In this way, audience resistance to what was deemed controversial in Dinner becomes clearer. Knowing that interracial marriage was culturally taboo, the filmmakers attempted to portray the relationship in as least offensive a way as possible in order to make the film tolerable for White audiences. The primary way this was accomplished was by depicting Prentice as a "desexualized Black hero" (Verney 69). In this way, the film flips the script on Mockingbird and a host of earlier films which show the Black man as sex-crazed and animalistic. It is important to note that this development of desexualization was not welcomed universally, with Blacks roundly 
denouncing it as dehumanizing. Thomas Cripps, for instance, critiques Poitier's acting choices, including Dinner's Prentice, as "African Americans consenting to be ruled" by White filmmakers (157).

\section{The Audience as Spectator}

The interplay between societal events and the film genre is central to how film can function as a form of moral critique. Lawrence Levine notes the importance of viewer participation to give a film meaning: "The audience's role in popular culture is not the passive reception of a given text but rather a question of translation; fitting the text into a meaningful context" (1384).

Carol Clover observes that trial films position the audience as "active spectators" who have a job to do (256). Linda Williams echoes Clover's view of the importance of trials, suggesting they are "...familiar ritual forms that...inform and structure popular American entertainment at the deepest level" (259). Moreover, she suggests, real and fictional "race trials have been especially important tests of the nation's ability to define itself as a democracy" (258). In the case of Mockingbird, audiences are watching the film nearly forty years after Jim Crow and in the wake of the Civil Rights movement, suggesting that their job while viewing the film is to be outraged over how unjustly Tom Robinson is being treated and to resolve to not perpetuate such savage inequalities. The film production sparsely pans the all-White male jury; instead, much of the filming shows Atticus Finch and the defendants speaking directly to the camera, as if they are pleading with the audience, not the courtroom jury. 
While Dinner is not a trial film, it functions in a similar fashion as Mockingbird. The camera remains largely focused on the father during his closing speech in which he delivers his consent of his daughter's interracial marriage, allowing the audience to feel as if they are the family partaking in the decision. Moreover, the act of viewing the first kiss through a rearview mirror allows the audience to feel like they are the taxi driver. These two choices serve to place the audience as key participants in the drama of the story which is a direct mirroring of societal politics in the country at the time.

\section{Conclusion}

Both Mockingbird and Dinner are staged amidst a society in ethical turmoil, almost as if the myths of racial separation, male domination, and poverty are coming to life on screen. Myths operate in men's minds without their being consciously aware of it, making it seem as though the thinking process itself were taking place in the myths (Levi-Strauss 12). Ultimately, I consider both of these films to be showing how America is coming of age in the Civil Rights Era. Just as Jem's journey in Mockingbird shows his transition from childhood to adulthood, I argue the film also suggests a societal journey from innocence to experience. The very different level of acceptance toward interracial relationships displayed in Dinner, only five years later, serves to convey how quickly societal shifts were taking place. Dinner takes on the issue of interracial relationships to show the country's transition and test the audience's growth in real time. Indeed, as Robert Sklar observes, "film... is both a necessary and an appropriate site for a dialogue ... over cultural representation and reception" (32). The United States was growing up alongside the films' Jem, Joey, and John and these films present a cultural interpretation of society and its 
changing times. Whether a film serves a moral critique of societal events seems to depend on your perspective as an audience member. Undoubtedly, however, these two films demonstrate how the genre of film acted as a vehicle to discuss social change in the Civil Rights Era, helping to drive reform and cultivate vital national conversations among audiences.

\footnotetext{
${ }^{1}$ In the interest of not superficially conflating two different genres, this essay does not address Harper Lee's 1960 book To Kill a Mockingbird.
} 


\section{Works Cited}

Appiah, Anthony K. “'No Bad Nigger': Blacks as the Ethical Principle in the Movies.” Media Spectacles. Eds. Garber, Marjorie, Jann Matlock, and Rebecca L. Walkowitz. New York: Routledge, 1993. 77-90. Print.

Cagle, Paul Christopher. Historical Foundations of Hollywood's Social Problem Film, 1945 1967. Diss. Brown University, 2005. UMI 3174579. Print.

Charrad, Mounira M. "Central and Local Patrimonialism: State-Building in Kin-Based Societies.” The ANNALS of the American Academy of Political and Social Science 636.1 (2011): 49-68. 27 August 2015. Web.

Clover, Carol J. "God Bless Juries!” Refiguring American Film Genres: Theory and History. Ed. Nick Browne, Berkeley: University of California Press, 1998. 255-77. Print.

Cripps, Thomas. "Making Movies Black: The Film Industry." Split Image: African Americans in the Mass Media. Eds. William Barow and Jannette L. Dates. Washington, D.C.: Howard University Press, 1990. 125-72. Print.

Douglass, Frederick. Narrative of the Life of Frederick Douglass, an American Slave. Wortley, near Leeds: Printed by J. Barker, 1846. Print.

Guess Who's Coming to Dinner? Dir. Stanley Kramer. Sony Pictures Home Entertainment, 2008. DVD.

Harris, Glen Anthony, and Robert Brent Toplin. “Guess Who's Coming to Dinner? A Clash of Interpretations Regarding Stanley Kramer's Film on the Subject of Interracial Marriage.” The Journal of Popular Culture 40.4 (2007): 700-713. Print.

Harris, Mark. Pictures at a Revolution: Five Movies and the Birth of the New Hollywood. 
New York: Penguin, 2008. Print.

Holcomb, Mark. “To Kill a Mockingbird.” Film Quarterly. 55.4 (2002): 34-40. Web. 29 October 2015.

Kramer, Stanley. “Guess Who Didn’t Dig Dinner?” New York Times 26 May 1968. Web. 29 October 2015.

Levi-Strauss, Claude. The Raw and the Cooked. Chicago: University of Chicago Press, 1990. Print.

Levine, Lawrence W. "The Folklore of Industrial Society: Popular Culture and Its Audiences.” The American Historical Review 97:5 (1992): 1369-1399. Print.

Mason, Clifford. "Why Does White America Love Sidney Poitier So?" New York Times 10 September 1967. Web. 29 October 2015.

Perrin, Anne Gray. “Guess Who's Coming to Dinner: The Web of Racial, Class, and Gender Construction in late 1960s America." The Journal of Popular Culture 45.4 (2012): 846-861. Print.

Romano, Renee C. Race Mixing: Black-White Marriage in Postwar America. Cambridge: Harvard University Press, 2003. Print.

Schatz, Thomas. Hollywood Genres: Formulas, Filmmaking, and the Studio System. Philadelphia: Temple University Press, 1981. Print.

Sklar, Robert. "Oh! Althusser! Historiography and the Rise of Cinema Studies." Radical History Review 41 (1988): 10-35. Print.

To Kill a Mockingbird. Dir. Robert Mulligan. Universal Studios, 1998. DVD.

Verney, Kevern. African Americans and US Popular Culture. New York: Routledge, 2003. Print.

Wells-Barnett, Ida B. "How Enfranchisement Stops Lynchings." Original Rights Magazine June 
1910 (2003): 42-53. Print.

Wheeler, Mark. Hollywood: Politics and Society. London: British Film Institute, 2006. Print. Williams, Linda. Playing the Race Card: Melodramas of Black and White from Uncle Tom to O.J. Simpson. Princeton, NJ: Princeton University Press, 2002. Print. 